\title{
Higher Education's Microcredentialing Craze: a Postdigital-Deweyan Critique
}

\author{
Shane J. Ralston ${ }^{1}$ \\ Published online: 19 May 2020 \\ (C) Springer Nature Switzerland AG 2020
}

\begin{abstract}
As the value of a university degree plummets, the popularity of the digital microcredential has soared. Similar to recent calls for the early adoption of Blockchain technology, the so-called 'microcredentialing craze' could be no more than a fad, marketing hype, or another case of 'learning innovation theater.' Alternatively, the introduction of these compact skills- and competency-based online certificate programs might augur the arrival of a legitimate successor to the four-year university diploma. The thesis of this article is that the craze for microcredentialing reflects (1) administrative urgency to unbundle higher education curricula and degree programs for greater efficiency and profitability and (2) a renascent movement among industry and higher education leaders to reorient the university curriculum towards vocational training.
\end{abstract}

Keywords Microcredentials $\cdot$ Blockchain technology $\cdot$ Digital technology $\cdot$ Higher education · Vocational education · John Dewey · Postdigital

As the value of a university degree plummets (Selingo 2017), the popularity of the digital microcredential has soared. Similar to calls for the early adoption of Blockchain technology (Ralston 2019), the so-called 'microcredentialing craze' could be no more than a fad, marketing hype, or another case of 'learning innovation theater' (Doran 2017; Maloney and Kim 2019). Alternatively, the introduction of these compact skillsand competency-based online certificate programs might augur the arrival of a legitimate successor to the four-year university diploma (Young 2017a, b). As of 2018, 20\% of colleges and universities offered for-credit and non-credit microcredentials, forecasted to be 30 to $40 \%$ within a decade (Gallagher 2018). The thesis of this article is that the craze for microcredentialing reflects (1) administrative urgency to unbundle higher education curricula and degree programs for greater efficiency and profitability and (2)

Shane J. Ralston

philsphizer@gmail.com

1 Wright College, Woolf University, Valletta, Malta 
a renascent movement among industry and higher education leaders to reorient the university curriculum towards vocational training.

The article is organized as follows. Part 1 defines the microcredential and explains its role in the neoliberal learning economy. Part 2 narrates the declining value of the university diploma relative to the microcredential. Part 3 presents the unbundled university and explores its relation to the postdigital perspective. Part 4 reveals how the surge in microcredentialing has sparked a critical response from some quarters. Many of these critics claim that the business partnerships between universities and third-party microcredentialing platform vendors undermine higher education's traditional mission. Part 5 describes the debate in the 1910s between the American educational philosopher John Dewey and vocational education innovator David Snedden. The aim of this historical inquiry is to demonstrate that the microcredentialers' campaign to repurpose higher education as a delivery mechanism for vocational training is a resurgent, not a new, movement. Part 6, the article's conclusion, proposes a postdigital-Deweyan critique of the microcredentialing craze. Also, the conclusion presents a series of suggestions for alternatives, or third-ways, between a traditional degree-based higher education model and a microcredentialdominated system of vocational education.

\section{Microcredentials and the Neoliberal Learning Economy}

The microcredential is a relative newcomer to the higher education scene. In the past 10 years, for-profit (e.g. Lynda.com, Coursera, and Udacity) and non-profit (e.g. EdX) learning platforms disrupted the higher education ecosystem by launching user-friendly Massive Open Online Courses (MOOCs) (Cooke 2020). The online divisions of major universities and colleges partnered with these platform providers, initially generating revenue through the provision of corporate training (Bogdan et al. 2017). With the bursting of the MOOC bubble (O’Malley 2019), platform developers parlayed their expertise into microcredentialing, designing compressed online courses with highly targeted curricula, suitable for employees of industries and corporations in need of workforce development; higher education institutions, seeking new revenue sources, quickly followed suit (Gallagher 2019).

Microcredentialing is an outgrowth of the neoliberal learning economy. In this economy, education resembles a commodity, a product, or service marketed and sold like any other commodity (Patrick 2013). Educational institutions adapt to competitive market pressures by behaving like profit-seeking firms, not only conceiving education as a commodity but also treating students and their employers as paying clients. Neoliberalism effectively extends the logic of capitalism into all areas of educational administration (Jandrić and Hayes 2019).

In the neoliberal learning economy, support for microcredentialing is particularly strong among higher education executives, administrators, and financial/tech-oriented staff who appreciate its value as an innovative profit center. As early as 2015, microcredentialing advocates had already announced that they were 'in the midst of' the craze:

We're in the midst of a credentials craze. As part of a growing movement to document students' skills and better prepare them for the workplace, an array of 
MOOCs [Massive Open Online Courses], private companies, industry groups, and colleges themselves are offering new types of credentials. The result is a proliferation of badges, certificates, microdegrees, and other types of credentials. Students might earn them for multiple skills covered in a single academic course, or they might bypass academe and learn those skills through a for-profit company like Lynda.com. (Mooney 2015)

Microcredentialing clients range from small start-ups to mid-sized companies to large corporations, and of course their employees. Courses in, for example, 3D printing, robotics, data analytics, employee recruitment, and supply chain management can be tailored to specific industries, employers, and even particular employees in order to close specific skills gaps (Carey 2015). There is also a revolving door between the online divisions of higher education institutions and third-party vendors of online platforms. For instance, the Chancellor of Purdue Global recently left to join Coursera (Seltzer 2020).

Even when delivered by higher education institutions, microcredentials are different than degrees. They typically encompass a limited series of modules or project-based units and cultivate a narrow range of skills or competencies. Microcredentials are sometimes aggregated, grouped, or 'stacked,' offering learners added flexibility, so that they can build their microcredentials into larger, more recognizable credentials (e.g. robotics and machine learning microcredentials could be stackable into an AI credential). According to two commentators, '[t]he more credentials learners accumulate and stack, the more they increase their currency in our knowledge economy, creating more direct pathways to better jobs and higher wages' (Williamson and Pittinksy 2016). Unlike a degree program, microcredentials typically lack a general education component, prioritizing instead the teaching of applied knowledge or vocational training for the sake of meeting employers' workforce needs (Craig 2015).

Microcredential programs are different than university degree programs in other ways too. Whereas private learning platforms often pair microcredentials with digital badges (an online validation of an achievement, skill, or competency), higher education institutions recognize microcredentials in the same way that they acknowledge certificates: the award of credits. Universities have also utilized Blockchain technology to verify the authenticity of microcredential certificates (Watters 2016; Johnson 2017). Although the coursework contributing to the microcredential can be applied to a degree program, many adult learners, believing that they are unsuited for college, prefer the short, targeted microcredential to a longer term, general education-based degree program (Carey 2015). Although the microcredential coursework is usually delivered online, there are often flexible alternatives (on-job-site, personal tutoring etc.) (Moroder 2014). When paired with learning analytics tools, learners can receive instantaneous feedback on their progress towards predetermined goals (Maseleno et al. 2018).

In industry, microcredentialing has become the preferred option for line managers and human resources professionals seeking to promote workforce development, whereas in a higher education, the landscape is still dominated by degree programs. For busy professionals, microcredentials offer several advantages over the four- or two-year university diploma: (1) reduced number of courses; (2) compressed time to completion; (3) greater affordability; (4) more relevance to the learner's career; and (5) more flexibility of learning options (Moroder 2014). Employers also recognize the value of 
microcredentialing. Research shows that lifelong learning and continuous workforce development boost employee morale, productivity, and retention (McLaren 2016; LinkedIn Learning 2018). Since microcredentials are short, skills-, and competencybased courses with more targeted curricula than a four or two-year degree program, they promise firms a quicker return on their investment in employee learning and development (D’Orio 2019).

However, microcredentials, unlike university degrees and certificates, are rarely accredited. The accreditation process for new degrees and majors can take multiple years, depending on the accrediting body, accreditation standards, and the rigor of the accreditation process. While the lack of regional accreditation could be viewed as a disadvantage, it is actually a benefit to many industries with urgent workforce development needs (Williamson and Pittinksy 2016). The pace of technological innovation and labor market trends requires increased speed and agility to meet learning and development needs. Strongly market-driven firms (e.g. high-tech and finance) must retrain their workforces to keep up with changing technology within a period of months, not years (D’Orio 2019). For these businesses, the speed of technological and market change dictates the need for quick and targeted microcredentialing. Waiting for the determination of an accrediting body is not an option.

Lastly, microcredentialing converts colleges and universities from degree-centric, two-level (undergraduate and graduate) institutions, preparing young adults for a lifetime of self-directed learning, to supply chain providers of education certifications (professional, continuing, and online), providing learning and training opportunities throughout an individual's entire life. Since industry-specific skills and competencies are always at risk of expiry - whether due to market- or technology-related pressures, including the automation of jobs - employees must constantly return to microcredential purveyors, paying to renew and update their skill sets (Cerf et al. 2019). Ultimately, the business model for microcredentialing is an architecture of planned obsolescence combined with the perpetual return of workers to commodified e-learning.

\section{The Decline of the Degree and the Rise of the Microcredential}

The market in educational credentials has always been highly competitive (Brown 2000). With microcredentialing on the upswing, the traditional degree faces new competition. Indeed, the demand for four-year undergraduate degrees and two-year post-graduate degrees has noticeably declined in the past decade. There has also been a parallel increase in employer demand for employees with 'skills, not degrees' (Kasriel 2018). Citing empirical research, expert commentaries, and media accounts, the author of the Chronicle of Higher Education report 'The Future of the Degree' predicts that the traditional undergraduate degree, once a minimum requirement to enter a skilled profession, will lose much of its value in the next decade. As the craze for microcredentials continues, the demand for traditional degrees declines. Indeed, the report concludes that 'American higher education is in the midst of a credentialing craze' (Selingo 2017).

Why is the university degree declining in value? One reason is unjustified entitlement. In the USA, ever since the passage of the 1944 GI Bill, high school graduates were expected to earn a college degree as a precondition for entering the professional 
workforce (Irvine 2017). Graduates were entitled to lucrative employment opportunities after earning a college diploma. However, in the 2000s, as recession hits the US economy, the American public lost confidence in the degree as a guarantor of upwards social and economic mobility. Observing the success of entrepreneurs, such as Bill Gates, Evan Williams, and Mark Zuckerberg - all college dropouts - the degree lost its shine. Many high-profile companies - for instance, Google, Penguin Random House, and Apple - now no longer require applicants to possess a degree (Glassdoor Team 2020). Consequently, the college diploma has lost its currency as a guarantor of entry into the professional workforce.

Another reason for the traditional degree's devaluation is the growing consensus that higher education is a private commodity, not a public good. In the twentieth-century, university disciplines, departments, research institutes, and degree programs of uneven quality proliferated through the largesse of state governments and a supportive taxpaying public. As public trust in higher education diminishes and state funding declines, public universities have increasingly looked to private industry for assistance. According to Stanford University's Mitchell Stevens, 'The patrons of higher ed are continuing to shift. We haven't reorganized our conception of how universities are supposed to be organized to accommodate that change' (Young 2017a). Nevertheless, higher education institutions have adapted to the shifting tectonics of financial support for higher education through a process Stevens labels 'recapitalization:' colleges and universities partner with Silicon Valley firms and other for-profit tech companies to offer in-demand skills- and competency-based credentials. Demand for these microcredentials is strongest within industry, especially the high-tech and financial sectors, where there is a pronounced need for fast-paced workforce development.

Yet another reason for the declining value of the university diploma is that employers no longer view the traditional degree as a reliable indicator of preparedness for the workplace. The present job market is flush with degreed candidates, whose diplomas have limited value for prospective employers. According to recent Federal Reserve Bank data, $41 \%$ of recent university graduates (degree-holders) in the USA are employed in jobs not requiring a degree (Redden 2020). Also, comparative earnings between non-degreed and degreed employees are equalizing (Fain 2020). Citing skills gaps and a lack of vocational knowledge, many business leaders view a university degree as poor preparation for future employment (McGarry 2018). Likewise, these employers do not believe that the earning of a university diploma is a reliable predictor of employee productivity or future job success (Chamorro-Premuzic and Frankiewicz 2019; Staton 2015).

As a result, partnerships between higher education institutions and companies seeking to remedy the skills gap by providing industry-specific, skill-, and competency-based microcredentials have surged (Salin 2019). According to one commentator, 'the boom in microcredentials is being fed in large part by major companies - IBM, Google, and Amazon, to name a few-looking to grow their talent pipeline and increase the skill level of current employees' (deLaski 2019). Microcredentialing also dovetails with the strategic human resources directive of many leading firms to retain top-performing employees and invest heavily in learning and development (McLaren 2016). A prime example is Starbucks Coffee's widely heralded College Achievement Plan, which pays $100 \%$ of employees' college tuition for job-relevant degree programs and microcredentials (Jackson 2018a). Despite the surge in 
partnerships between universities, employers, and learning platform vendors, Kazin and Clerkin (2018) note that the microcredentialing craze and the parallel decline of the degree repudiate rather than affirm the traditional mission of higher education institutions: '[T] he downsizing of the degree constitutes a rebuke to the higher education establishment, even if the establishment itself is creating them. There is a serious mismatch between degrees and what people actually need to launch or advance career' (3).

\section{The Unbundled University and the Postdigital Perspective}

The administration of higher education is notoriously inefficient. Registering students. Scheduling classes. Processing transcript requests. Facilitating shared governance. Many of these processes are nearly as labor-intensive as they were 50 years ago. One way to address inefficiencies in higher education administration is to conduct performance studies, identifying relevant metrics of success (so-called 'Key Performance Indicators' of KPIs), measuring outcomes, and eliminating excess and waste in these administrative processes (Jackson 2018a, b). Another is to adopt new, more efficient digital technologies - for instance-Blockchain which stores data in immutable blocks for the sake of streamlining administrative processes, such as degree authentication, peer-to-peer payment, contracts, and recordkeeping (Clark 2016; Sharples and Domingue 2016; Chen et al. 2018; Ralston 2019). Yet another is to model higher education after a private business venture, strategically planning as a private firm does, minimizing costs and maximizing profits (Scott 2018). Within the past century, all three approaches - performance studies, technological innovation, and strategic planninghave been utilized by universities and colleges, alone or in combination, to make educational administration more efficient. Since the early twentieth-century, Taylorism or scientific management also provided higher education administration with a model of efficient operation, utilizing time and motion or task-time-to-completion studies (Ireh 2016).

The contemporary vision of the unbundled university offers another mechanism for streamlining educational administration. As state funding for higher education shrank, more colleges and universities were forced by economic circumstances to change their funding model and search for new revenue streams. Accordingly, unbundling should be appreciated within the context of the emergent neoliberal learning economy:

...unbundling did not happen in a vacuum. It happens in the era of neoliberal globalization that sees rampant commercialization in the higher education marked by quantified competition for excellence and success measured by metrics of individual performance and world rankings. (Ivancheva 2020:9)

One way to improve program efficiency and profitability is to unbundle educational products and services. As a hypothetical example, imagine a university's English Department that is at risk of closure because of a history of declining majors. The department's chair identifies the Ethics curriculum in the English Baccalaureate as an opportunity to save the department. The chair unbundles the Ethics component from the English B.A. degree program and offers it as a freestanding Minor. The intention 
behind this unbundling strategy is to enhance efficiency (i.e. the same number of faculty instructing more students, including non-majors) and generate revenue (i.e. more tuition collected from English course offerings). By segmenting or unbundling an existing curriculum, academic departments effectively create new profit centers.

Another way to unbundle the curriculum is in terms of specific competencies or skills, offering relevant microcredentials to professionals and pre-professionals in exchange for a fraction of the tuition for a full degree. An excellent example is the collaboration between Massachusetts Institute of Technology (MIT) and the non-profit $\mathrm{EdX}$ to offer MicroMasters degrees in supply chain management:

The program follows the same curriculum as MIT's in-person master's program, except that it covers only about $30 \%$ of that material (which is why it is a 'micro' degree). That means students take five courses (and pay $\$ 1000$ in fees) to get the MicroMasters. There is no admissions process, so if a student can do the work, he or she can earn the credential, and for students in the online program who do well enough to gain admission to MIT's in-person master's, the online credits transfer, making that degree less expensive.

The program recently graduated its first batch of online students, and so far, the supply chain MicroMasters has brought in more than $\$ 4$ million in revenue, according to Anant Agarwal, CEO of EdX. That money is split between MIT and EdX, which provides the platform and marketing for the courses. (Young 2017b)

The MIT-EdX MicroMasters is not only more profitable than its predecessor; it is also more efficient. By unbundling MIT's traditional Master's degree in Supply Chain Management, reconstituting it as a MiniMasters with $30 \%$ of the original curriculum and delivering it exclusively online, the outcome is that more paying customers/ students can be taught with the same number of workers/faculty (Durant and Tracky 2017).

Unbundling did not originate within universities, colleges, and non-profits, though. By the late 1960s and early 1970s, the first unbundling projects were undertaken by technology and entertainment firms, seeking to segregate hardware and software for the sake of maximizing profits:

[U]nbundling is not merely an educational concept but also a technological and corporate one; a neologism that emerged in the computing sector, with the pivotal event being IBM's separation of software and services from hardware sales in 1969. This led to dramatic market expansion and the birth of the software industry. Technology-based unbundling was also a highly disruptive phenomenon in the music and home entertainment industries. (Swinnerton et al. 2019)

Similar to a factory assembly-line, reducing larger products into smaller ones makes production more efficient and permits the monetization of multiple components, rather than simply limiting sales to whole assemblies. With state funding and public support for higher education on the wane, the unbundling strategy, adopted by economically pressured colleges and universities, boosts revenue and efficiency.

Besides unbundling, another process that streamlines educational administration is servitization. When higher education institutions partner with third-party vendors to 
provide microcredentials, they effectively convert goods into services. Borrowed from the manufacturing sector, servitization is when a 'tangible product is replaced or supplemented by an intangible service' (Arantes 2020). The intentional entanglement of product and service, as well as the ensuing confusion over which is on offer, contributes to a scheme of increased revenue generation (Tauqeer and Bang 2018). An example is AirBnB, which does not itself offer cheaper accommodation, but only a service to connect landlords with prospective renters of short-term accommodations and charge both a service fee for the platform, introduction, and transaction. Nevertheless, AirBnB is often confused with a provider of goods, namely, vacation rental properties. Servitization also operates in the world of microcredentialing. Without having to improve the already given or established market offering (i.e. online education), an established brand (e.g. MIT) partners with a service provider (e.g. EdX) to grant microcredentials (i.e. short, targeted, skills-based online courses modeled after existing MOOCs) in order to generate new revenues from industry and corporate clients. To ensure long-term profitability, learners must return to the microcredential servicer to update their credentials or stack them towards achieving more tangible credentialing goals.

What is the relationship between unbundling, servitization and the postdigital? The postdigital is a perspective that treats all technologies - whether digital or non-/predigital — as having equal standing (Jandrić 2019). The postdigital perspective refuses to privilege one technology over another simply because of its digital format (Fawns 2019; Feenberg 2019). Non-digital or pre-digital technologies (e.g. group meetings, classroom instruction, and communal gardening) tend to build a sense of community and belonging through face-to-face, personal interaction. Although digital technologies can facilitate meaningful human interaction-for instance, in online courses and digitally mediated communications - blending them with face-to-face meetings (predigital technology) has been shown to improve learning outcomes (López-Pérez et al. 2013). In other words, digital learning technology should not be treated as superior to non-digital technology purely in virtue of its digital pedigree. Unfortunately, unbundling higher education products and servitizing them on digital platforms risks divorcing a crucial human and non-digital element from the curriculum (deLaski 2019).

\section{Microcredentialing and its Discontents}

While microcredentialing has found widespread support among industry leaders and higher education administrators, it has also sparked criticism and resistance by university faculty and students. Many of these dissidents also criticized the early adoption of MOOCs. For instance, in 2013, professors at San Jose State University, after being advised by administrators to replace their lectures with EdX's online content, protested in an open letter:

Let us not kid ourselves; administrators . . . are beginning a process of replacing faculty with cheap online education. [. . ] Should one-size-fits-all vendordesigned blended courses become the norm, we fear that two classes of universities will be created. Public universities will no longer provide the same quality of education and will not remain on par with well-funded private ones. (EvoLLLution Newswire 2013) 
The microcredentialing craze has incited the same fears and concerns among college faculty, specifically that fully automated online course delivery systems will thoroughly replace teaching staff.

Some of these discontents also believe that the distinction between for-profit elearning industry and public higher education has become so blurred that there is no longer any meaningful difference. In the words of one critic,

I no longer think there's a huge difference between for-profit and public higher education. Sit in enough faculty meetings, meet with enough leadership, and it becomes clear that it's all about money. The difference between for-profit and public is mainly about appearances. In public institutions, we claim the higher ground but almost everything is driven by student numbers, enrolment, and dollars. Education could be less expensive, it could be more engaging, it could have a bigger impact, but we are confined to a system that values dollars first. (Young 2019)

The higher education project to repackage curricula as microcredentials and sell them to industry for the purpose of workforce development attests 'to a system that values dollars first.' As microcredentialing purveyors, colleges and universities also make themselves increasingly subservient to their new clients: businesses and corporations in need of rapid, targeted vocational training for their employees.

On a more technical level, critics question how to validate the comparative worth of microcredentials issued by different sources. For instance, how would an employer know whether a job candidate's mini-degree in Robotics granted by EdX (a joint Harvard-MIT venture) was more or less challenging to earn than a microcredential by the same name awarded by the University of Oregon? (Doran 2017) Lacking program accreditation, microcredentials are not comparable in the same way that degrees and certificates are. In an ad hoc comparison, an employer would likely determine that the EdX microcredential is of greater value for the simple reason that the institutions of Harvard and MIT are ranked higher than the University of Oregon (U.S. News and World Report 2020). Besides being inexact, the ad hoc method of assessing comparative worth also reveals that, without accreditation, efforts to ensure that microcredentials meet minimum standards of educational quality are fruitless. Quality assurance amounts to knee-jerk impressions of institutional reputation, not rigorous assessments of program structure, faculty strength, and curriculum quality (Krupnick 2018).

For other discontents, the surge in partnerships between public higher education institutions and third-party microcredentialing vendors signals a radical departure from the traditional mission of higher education institutions. According to one critic, the goals of credentialing and higher education are starkly different and often at odds:

Credentials document and validate a person's knowledge and skills. Higher education, in contrast, has traditionally had broader goals to instill a wide range of literacies (including cultural, scientific, and numerical literacies, communication, collaboration, and problem-solving skills, and a college-level capacity for critical thinking and ethical reasoning) and document a host of other attributes, including perseverance, self-discipline, and the ability to multitask. 
What distinguished higher education from a correspondence course (and its updated, digitized successors) was regular, substantive interaction with a professor and classmates and ongoing scaffolding, mentoring, constructive feedback, and assessment from a recognized scholar. (Mintz 2019)

What is lost in the conversion of higher education to a microcredentialing delivery system is the rich educational experience whereby teacher-scholars share new vocabularies, culture and dispositions to learn with their students in an ongoing and mutually edifying conversation. Also abandoned is the higher purpose of education: namely, to serve society-at-large, not simply corporations and industry.

In sum, microcredentialing's discontents worry that by unbundling degree programs and curricula in order to generate new profit centers, higher education institutions have sold their soul to business interests. Their traditional mission of enabling student growth through transformative teaching is traded for a corporate mission of maximizing efficiency and profitability at all costs. As a result, universities and colleges become public in name only; their daily operations dictated by business strategy and revenueseeking activities (Young 2019). Thus, for microcredentialing's critics, the craze represents a betrayal of higher education's higher purpose and a loss for students and faculty who continue to see university learning as more than vocational training.

\section{John Dewey and the Vocationalists}

Although the digital technology associated with microcredentialing technology is new, the movement to reorient higher education from its traditional mission to the purpose of providing vocational training is not. Indeed, the campaign to reconfigure colleges and universities so that they serve workforce development needs dates to at least the early twentieth-century. In the American context, it can be traced back to the 1910s, specifically to a debate between the educational philosopher John Dewey and the vocational training advocate David Snedden.

2020 is not the first year that the Dewey-Snedden debate became relevant again. In the 1970s, the journal Curriculum Inquiry reprinted most of the debate with commentary by Snedden's biographer, Walter H. Drost (1979). The occasion for reintroducing the 60 -year-old debate was the reemergence of vocational education as a topical issue, this time repackaged and resold to educational leaders by industry executives as so-called 'career education' (Labaree 2010: 2). Microcredentialing for employment education can be appreciated as the current incarnation of the highereducation-as-vocational-training movement. After 40 years, industry and financial elites return with a timeless message: colleges and universities must prepare learners to become good workers (Kafka 2019).

The opening salvo in the debate was launched by Snedden. In July 1914, Sneddenat the time, the Commissioner of Education for the state of Massachusetts - gave a speech challenging the distinction between liberal and vocational education. In the speech, Snedden (1914/1977) argued that the old style of liberal education, heavily reliant as it was on custom and 'mysticism,' could no longer be defended as higher learning. To be higher, liberal education required a modern focus on commercial 
usefulness and vocational preparedness. Modern liberal education had to be a 'form of education designed to equip a young person for a recognized calling:'

the most useful definition of liberal education now available is that which defines it primarily in terms of education towards higher utilization. Man stands, to the world about him, in a twofold relationship. He is a producer of utilities on the one hand, and on the other, for his own growth and development, he must utilize utilities. That education which trains him to be a producer is vocational education. That education which trains him to be a good utilizer, in the social sense of that term, is liberal education (157).

Snedden concluded that the best way to reform liberal education is to entirely separate it from its academic roots, 'reproduc[ing] as fully as possible the atmosphere of economic endeavor in the field for which it trains' (160).

Dewey penned two articles on vocational education. In the first, titled 'On Industrial Education,' Dewey argued that vocationalists like Snedden erred in two respects: (1) their vision of vocational education is too closely allied with the interests of industrialists to serve the greater public interest, and (2) it suggests an imprudent approach to educational reform, whereby no meaningful change is ever forthcoming. Vocationalism merely props up the status quo, a disappointing state of industrial relations warranting the continued exploitation of workers by management. In Dewey's (1914/1977: 55) words, vocational education 'takes for granted the perpetuity of the existing industrial regime, and whose inevitable effect is to perpetuate it, with all its antagonisms of employers and employed, producer, and consumer'. In response, Snedden protested that Dewey's analysis did not undermine the argument for vocational education, but simply implied a need for two kinds of higher education: (1) classical liberal education for the elites and (2) vocational education for the 'rank and file' (Dewey and Snedden 1915/1977: 35).

In Dewey's second article, 'Education v. Trade-training,' he proposed a view of vocational education more congenial to the traditional mission of higher education. According to the traditional mission, institutions should facilitate student learning and growth through transformative teaching. Not only did Dewey reject Snedden's elitist division of education according to the needs of socio-economic classes, he also proposed a better alternative:

I would go farther than he [Snedden] is apparently willing to go in holding that education should be vocational, but in the name of a genuinely vocational education I object to the identification of vocation with such trades as can be learned before the age of, say, eighteen or twenty; and to the identification of education with acquisition of specialized skill in the management of machines at the expense of an industrial intelligence based on science and a knowledge of social problems and conditions. I object to regarding as vocational education any training which does not have as its supreme regard the development of such intelligent initiative, ingenuity and executive capacity as shall make workers, as far as may be, the masters of their own industrial fate. [ . .] I am regretfully forced to the conclusion that the difference between us is not so much narrowly educational as it is profoundly political and social. The kind of 
vocational education in which I am interested is not one which will 'adapt' workers to the existing industrial regime; I am not sufficiently in love with the regime for that. It seems to me that the business of all who would not be educational time-servers is to resist every move in this direction, and to strive for a kind of vocational education which will first alter the existing industrial system, and ultimately transform it (Dewey and Snedden 1915/1977: 38-39).

In contrast to Snedden, Dewey conceived industrial education through a larger lens, not as narrow training for specific trades or vocations but as (1) preparation for a life of curiosity and inquiry, (2) the cultivation of 'an industrial intelligence based on science and a knowledge of social problems and conditions,' and (3) 'the development of intelligent initiative, ingenuity, and executive capacity.' Higher learning should educate the whole person for the sake of a higher quality life, not simply transmit specific hard skills and technical competencies suitable for work. By providing vocational training exclusively, higher education institutions cut their students off from more elevated pursuits (e.g. art, history, cultural studies) and condemn them to a life of subservience to their industrial and corporate masters. On Dewey's account, higher education should uplift learners, liberating their potentiality and empowering them to become 'masters of their own industrial fate.'

The resurgence of the higher-education-for-vocational-training movement could be interpreted as another sign that Snedden and the vocationalists, not Dewey, won this debate (Labaree 2010: 5; DeFalco 2016: 57). However, there is proof that Dewey's case for a more liberalized form of vocational education has also stood the test of time. In a speech titled 'Learning to Earn,' Dewey introduced the distinction between the process of learning-to-earn and learning-by-doing (Dewey 1917/1996). Learning skills and competencies associated with industrial efficiency-so-called 'learning-to-earn'- does not foster the fundamental habits or dispositions that enable future self-directed learning — what Dewey termed 'learning-by-doing' and, more recently, educational psychologists and curriculum designers label 'learning-to-learn' (Hofer and Yu 2003; Wingate 2007). For instance, by first taking an intensive course on Aristotelian logic (now widely considered dated given the lack of existential import in modern Boolean logic), a computer engineering student learns habits of logical reasoning and dialogthe so-called 'fundamentals' - necessary for her to later master the technicalities of coding (Walton 2000).

The modern microcredentialing craze is an outgrowth of a renascent movement to repurpose universities as sites (then place-based and now virtual) for vocational training and workforce development. Similar to today's microcredentialing advocates, vocationalists in the early twentieth-century were far more concerned with developing industry-specific competencies that improve a worker's earning potential - that is, learning-to-earn - than cultivating habits of learning-to-do (or learning-to learn). However, acquiring technical skills is not the exclusive point of industrial - or what we nowadays call 'professional' or 'employment' - education. Soft skills or human competencies (e.g. in negotiation, conflict resolution, emotional intelligence) are also requisite for professional development and personal growth (Wilhelm et al. 2002; Grugulis and Vincent 2009). Organizational psychologists demonstrate that a critical determinant of securing gainful employment and achieving career success is the accrual of these soft skills (Hogan et al. 2015). 
The upshot of Dewey's critique of Snedden is that higher education ought to liberate the potentialities of learners, not foreclose opportunities for further education by limiting a learner's development to the uptake of technical or vocationally oriented skills. Unfortunately, the process of unbundling curricula as microcredentials - as well as servitizing and stacking them-restricts learners to a never-ending wheel of credential servicing. Corporate and industry employers exert pressure on their employees to continually return to profit-seeking vendors and educational institutions to update expired skills and competencies. Lifelong learning, in this sense, enslaves rather than liberates the learner. In sum, the microcredentialing for employment educationis not a new movement, at least not in its emphasis on converting universities into providers of vocational training. It is, at best, a renascent movement with a digital twist.

\section{A Postdigital-Deweyan Critique of Microcredentialing}

In advancing a postdigital-Deweyan critique, ten issues with microcredentialing arise:

1) Microcredentialing is dangerously reductivist. It reduces higher learning to a list of hard skills and technical competencies that bolster employer workforce development and heighten employees' earning potential. Soft skills and human competencies to, for instance, 'learn to learn' are arbitrarily excluded from microcredential curricula, even though they contribute to career development and personal growth (Wilhelm et al. 2002; Grugulis and Vincent 2009).

2) Microcredentialing contributes to the decline of the traditional degree. It paves the way for the total substitution of degree programs with microcredentials. For instance, Kazin and Clerkin (2018: 3) ask, '[w]hy should an individual bother to pursue a full master's degree if five courses alone are enough to confer career success?'.

3) Microcredentialing undermines the mission of higher education institutions. It makes efficiency and profitability the guiding values of higher education administration, not student learning and growth. Consequently, universities and colleges increasingly imitate the structures and operations of businesses and corporations, neglecting their traditional roles as institutions for knowledge creation, sharing, and preservation. Unbundling, servitization, and other strategic solutions enslave higher education to commercial ends - eliminating inefficiencies, minimizing costs and maximizing profit - rather than to goals aligned with the interest of students and society-at-large.

4) Microcredentialing poses a moral hazard by premising further learning on a transactional, profit-driven relationship between universities, clients, and vendors. Insofar as stacked microcredentials commodify the process of learning, employers may require that learners continually return to educational institutions and their third-party vendors to purchase access and update outdated skills and competencies. In the neoliberal learning economy, microcredentialing generates a consistent stream of revenue through planned obsolescence, perpetual servicing, and moral hazard. Administrators invested in microcredentialing as a revenue generator will sometimes have to shirk their ethical duty to act in the best interests 
of students in order to maximize profits. To address the moral hazard, some commentators have recommended institutional self-regulation (Phelan and Glackin 2020), while others have suggested ethical classification of microcredential programs (Willis III et al. 2016).

5) Microcredentialing does not liberate learners' potentialities or meet the needs of lifelong learners. As Dewey insisted, education should empower students to learn by doing (or learn-to-learn), rather than learn-to-earn. Since microcredentials pertain exclusively to the acquisition of industry-specific skills and competencies, they do not cultivate habits of intelligent inquiry that are fundamental to intellectual curiosity and self-exploration. Commercially driven microcredentialing does not satisfy the curious lifelong learner, who seeks to learn for the sake of learning (as an end-in-itself), not for the sake of expanding their earning potential.

6) Microcredentialing's focus on vocational education allies it with vested industrial and corporate interests. Despite the claims of corporate managers and human resource (especially learning and development) professionals, microcredentialing is not aligned with the interests of industrial/technical workers and marginalized communities. For Weberians, credentialism is a strategy for limiting resource access to only those with formal qualifications, thereby ensuring that the credentialed alone reap the greatest social and financial rewards (Brown 2000). For Marxists, credentialism suggests bourgeois values that, when pursued by members of the proletariat, generate a version of false consciousness. Workers contribute to their own exploitation by internalizing the logic of capitalism and pursuing the elusive final credential (or microcredential), unaware that the credentialing process is profit-driven and therefore lacks a definite terminus (McNally 1993).

7) Microcredentialing's emphasis on vocational training supports the status quo rather than genuine educational reform that would improve workers' lives and industrial-social conditions. Similar to the Marxist critique of factory production (McNally 1993), the problem with unbundling in a university context is that it alienates human beings from the products of their labor (e.g., students, curricula, credentials), elevating the significance of industrial and corporate ends over educational ends. If inequality between owners of capital and workers, who solely own and sell their labor, is to end, microcredentialing will not bring it about. Instead, bonafide social change requires a more holistic approach to higher education.

8) Microcredentialing is unconcerned with educating the whole person. Unlike Liberal Arts education, which catalyzes changes in the entire character of the learner, vocationally oriented microcredentialing seeks only to transfer hard skills and technical competencies to the client-learner. In the absence of a General Education component, microcredentialing tends to cultivate only a single dimension, aspect, or element of the learner's character, effectively producing a technician, not a well-rounded person. Past president of the University of Chicago, Robert Hutchins (1936/1958), voiced a similar complaint about vocational training: 'The pursuit of knowledge for its own sake is being rapidly obscured in universities and may soon be extinguished. [ . .] [S]oon everybody in a university will be there for the purpose of being trained for something. [ . .] It is plain, though, that it is bad for the universities to vocationalize them' (36-7). Insofar as 
microcredentialing fails to educate the whole person, it exacerbates one symptom of the neoliberal learning economy, namely, the turn away from pursuing knowledge for its own sake and towards learning to earn (Siskin and Warner 2019).

9) Microcredentialing, similar to earlier vocational education, threatens to exacerbate class divisions. If microcredentialing is only seen as a pathway to education for technical and industrial workers, it effectively brackets them off from elites and members of the upper socio-economic class, who become the sole beneficiaries of classic liberal arts education (Dewey 1914/1977).

10) Microcredentialing delivery systems unjustifiably privilege digital over nondigital or pre-digital technologies. Internet and Blockchain technologies are integral to the transmission of microcredentialing curricula (similar to their predecessors, MOOCs). Insofar as the postdigital perspective insists that digital and pre-digital technologies should have equal standing, privileging digital technology is thoroughly unjustified (Jandrić 2019). Digital technology ought not to be favored solely in virtue of its digital pedigree (Fawns 2019; Feenberg 2019).

The postdigital affords opportunities to meliorate the effects of the microcredentialing craze by reintroducing a distinctly human element into the mix. For instance, while microcredential programs emphasize the teaching of hard or technical skills (e.g. computer coding or supply chain management), a postdigital alternative is to utilize them to cultivate human, critical, or soft skills too (Haber 2020; McDonough 2020). This requires not only the introduction of new curricula but also a major reorientation of perspective. Mintz (2019), similar to John Dewey and Robert Hutchins before him, notes that acquiring skills is not the sole purpose of professional education: '[P]reparation for a profession ought not to be limited to skills-training; it should involve professional identity formation, which is much more holistic. A professional is not a technician. (Nor should a technician simply be someone with technical skills).' Technicians often lack a sufficiently wide-ranging or general (Liberal Arts) education to appreciate the limits of their own knowledge - or stated differently, the extent of their own ignorance. Thus, tech entrepreneurs such as Mark Zuckerberg, Elon Musk, and Bill Gates are often too willing to position themselves as authorities in fields where they lack expertise (e.g. concerning world poverty, global climate change and, most recently, epidemiology). Also, a renewed focus on cultivating soft skills and educating the learner holistically could potentially reinvigorate the value of the university diploma: '[U]niversities could substantially increase the value of the college degree if they spent more time teaching their students critical soft skills' (Chamorro-Premuzic and Frankiewicz 2019). In this way, the traditional degree (a pre-digital artifact) could coexist side-by-side with the (digital) microcredential, instead of the latter spelling the end of the former.

My critical treatment of microcredentialing will likely be classified as simply another neo-Luddite reaction to the wave of technological progress that the higher education sector is currently undergoing. Slowing the neoliberal learning economy's expansion is extremely difficult; stopping it, nearly impossible. The recent massive institutional switch to fully online teaching as an emergency response to the global Covid-19 pandemic is a case in point (Jandrić 2020). Likewise, the craze for microcredentialing continues apace with rapid technological change in the higher education space, viewed by many educational futurists as a panacea for skills gaps, 
workforce stagnation, and automation-induced labor market shocks. Disagreements will likely persist among higher education experts as to whether microcredentialing, with its constituent processes of unbundling and servitization, is an acceptable longterm strategy for institutions concerned to survive and thrive in a highly competitive education marketplace. The postdigital-Deweyan critique proposed in this article suggests a more deliberative and constructive approach to microcredentialing, an sound alternative to the current craze.

\section{References}

Arantes, J. A. (2020). The servitization of Australian K-12 educational settings. Postdigital Science and Education. https://doi.org/10.1007/s42438-019-00097-0.

Bogdan, R., Holotescu, C., One, D., \& Grosseck, G. (2017). How MOOCs are being used for corporate training? ResearchGate, 15 April. https://www.researchgate.net/publication/316076362_HOW_ MOOCS_ARE_BEING_USED_FOR_CORPORATE_TRAINING. Accessed 3 March 2020.

Brown, D. K. (2000). The social sources of educational credentialism: status cultures, labor markets, and organizations. Sociology of Education, 74, 19-34. https://doi.org/10.2307/2673251.

Carey, K. (2015). Here's what will truly change higher education: online degrees that are seen as official. New York Times, 5 March. https://www.nytimes.com/2015/03/08/upshot/true-reform-in-higher-educationwhen-online-degrees-are-seen-as-official.html. Accessed 3 March 2020.

Cerf, M., Tybout, A.M., \& Calkins, T. (2019). Using neuroscience to assess brands. In A.M. Tybout \& T. Calkins (Eds.), Kellogg on branding in a hyper-connected world (pp. 207-217). Hoboken, NJ: Wiley.

Chamorro-Premuzic, T., \& Frankiewicz, B. (2019). Does higher education still prepare people for jobs? Harvard Business Review, 7 January. https://hbr.org/2019/01/does-higher-education-still-prepare-peoplefor-jobs. Accessed 3 March 2020.

Chen, G., Xu, B., Lu, M., \& Chen, N. (2018). Exploring blockchain technology and its potential applications for education. Smart Learning Environments, 5(1). https://doi.org/10.1186/s40561-017-0050-x.

Clark, D. (2016). 10 ways blockchain could be used in education. OEB Insights. https://oeb.global/oebinsights/10-ways-blockchain-could-be-used-in-education/. Accessed 3 March 2020.

Cooke, D. (2020). MOOCs: massive disruption in higher education. The EvoLLLution. https:/evolllution. com/revenue-streams/distance_online_learning/massive-disruption-moocs-higher-education/. Accessed 3 March 2020.

Craig, R. (2015). The other postsecondary education. Inside Higher Education, 15 October. https://www. insidehighered.com/views/2015/10/15/colleges-alone-cant-solve-skills-standoff-employers-essay. Accessed 3 March 2020.

D’Orio, Wayne (2019). What's in a microcredential? EducationDive, 11 June. https://www.educationdive. com/news/whats-in-a-microcredential/556606/. Accessed 3 March 2020.

DeFalco, A. (2016). Dewey and vocational education: still timely? The Journal of School and Society, 3(1), 54-64.

deLaski, K. (2019). As the microcredential market booms, don't forget the learner. EdSurge, 31 October. https:/www.edsurge.com/news/2019-10-31-as-the-microcredential-market-booms-don-t-forget-thelearner. Accessed 3 March 2020.

Dewey, J. (1914/1977). On industrial education. Curriculum Inquiry, 7(1), 53-60. https://doi.org/10.1080 /03626784.1977.11076204.

Dewey, J. (1917/1996). Learning to earn: the place of vocational education in a comprehensive scheme of public education. In J.A. Boydston (Ed.), The Collected Works of John Dewey, 1882-1953 (p.144). Carbondale and Edwardsville: Southern Illinois University Press. https://doi.org/10.1037/10903-000.

Dewey, J., \& Snedden, D. (1915/1977). Two communications. Curriculum Inquiry, 7(1), 33-39. https://oi. org/10.1080/03626784.1977.11076202.

Doran, L. (2017). Are microcredentials a fad or the future? InsideSources, 8 May. https://www.insidesources. com/microcredentials-fad-future/. Accessed 3 March 2020.

Drost, W. H. (1979). Social efficiency reexamined: the Dewey-Snedden controversy. Curriculum Inquiry, 7(1), 19-32. https://doi.org/10.1080/03626784.1977.11076201. 
Durant, E., \& Trachy, A. (2017). Digital diploma debuts at MIT. Massachusetts Institute of Technology News, 17 October. http://news.mit.edu/2017/mit-debuts-secure-digital-diploma-using-bitcoin-blockchaintechnology-1017. Accessed 3 March 2020.

EvoLLLution Newswire. (2013). Professors say no to MOOC takeover. The EvoLLLution, 10 May. https://evolllution.com/revenue-streams/distance_online_learning/professors-mooc-takeover/. Accessed 3 March 2020.

Fain, P. (2020). Overlap in labor market returns for diplomas and degrees. Inside Higher Education, 17 February. https:/www.insidehighered.com/quicktakes/2020/02/27/overlap-labor-market-returnsdiplomas-and-degrees. Accessed 3 March 2020.

Fawns, T. (2019). Postdigital education in design and practice. Postdigital Science and Education, 1(1), 132145. https://doi.org/10.1007/s42438-018-0021-8.

Feenberg, A. (2019). Postdigital or predigital? Postdigital Science and Education, 1(1), 8-9. https://doi. org/10.1007/s42438-018-0027-2.

Gallagher, S.R. (2018). Educational credentials come of age: a survey of the use and value of educational credentials in hiring. Boston, MA: Northeastern University. https:/www.northeastern.edu/cfhets/wpcontent/uploads/2018/12/Educational_Credentials_Come_of_Age_2018.pdf. Accessed 3 March 2020.

Gallagher, S.R. (2019). A new era of microcredentials and experiential learning. University World News, 15 February. https://www.universityworldnews.com/post.php?story=20190213103113978. Accessed 3 March 2020.

Glassdoor Team (2020). 15 more companies that no longer require a degree-apply now. Glassdoor. https://www.glassdoor.com/blog/no-degree-required/. Accessed 3 March 2020.

Grugulis, I., \& Vincent, S. (2009). Whose skill is it anyway?: 'soft' skills and polarization. Work, Employment and Society, 23(4), 597-615. https://doi.org/10.1177/0950017009344862.

Haber, J. (2020). It's time to get serious about teaching critical thinking. Inside Higher Education, 2 March. https://www.insidehighered.com/views/2020/03/02/teaching-students-think-critically-opinion. Accessed 3 March 2020.

Hofer, B.K., \& Yu, S.L. (2003). Teaching self-regulated learning through a 'Learning to Learn' course. Teaching of Psychology, 30(1), 30-33. https://doi.org/10.1207/S15328023TOP3001_05.

Hogan, R., Chamorro-Premuzic, T., \& Kaiser, R. B. (2015). Employability and career success: bridging the gap between theory and reality. Industrial and Organizational Psychology, 6(1), 3-16. https://doi. org/10.1111/iops. 12001 .

Hutchins, R.M. (1936/1958). Higher learning in America. New Haven: Yale University Press.

Ireh, M. (2016). Scientific management still endures in education. Winston-Salem, NC: Winston Salem State University. https://files.eric.ed.gov/fulltext/ED566616.pdf. Accessed 3 March 2020.

Irvine, J. (2017). Confronting the skills gap — are higher education graduates career ready? Chalk \& Wire, 11 December. http://www.chalkandwire.com/confronting-the-skills-gap-are-higher-education-graduatescareer-ready/. Accessed 3 March 2020.

Ivancheva, M. (2020). Unbundling: a new gendered frontier of exclusion and exploitation in the neoliberal university. Journal of New Materialist Research, 1, 80-109. https://doi.org/10.1344/jnmr.v1i1.29204.

Jackson, A.A. (2018a). Coffee and college: how Starbucks is investing in its employees' future. Glassdoor, 8 May. https://www.glassdoor.com/blog/starbucks-college-achievement-plan/. Accessed 3 March 2020.

Jackson, T. (2018b). Key performance indicators for schools and education management. Clearpoint Strategy. https:/www.clearpointstrategy.com/key-performance-indicators-in-education/. Accessed 3 March 2020.

Jandrić, P. (2019). We-think, we-learn, we-act: the trialectic of postdigital collective intelligence. Postdigital Science and Education, 1(2), 275-279. https://doi.org/10.1007/s42438-019-00055-w.

Jandrić, P. (2020). Postdigital research in the time of Covid-19. Postdigital Science and Education. https://doi. org/10.1007/s42438-020-00113-8.

Jandrić, P., \& Hayes, S. (2019). Post-digital we-learn. Studies in Philosophy and Education. https://doi. org/10.1007/s11217-020-09711-2.

Johnson, S. (2017). In the era of microcredentials, institutions look to blockchain to verify learning. EdSurge, 31 October. https:/www.edsurge.com/news/2017-10-31-in-the-era-of-microcredentials-institutions-lookto-blockchain-to-verify-learning. Accessed 3 March 2020.

Kafka, A.C. (2019). Want to be a happy prof? Teach kids how to get jobs. The Chronicle of Higher Education, 2 June. https://www.chronicle.com/article/Want-to-Be-a-Happy-Prof-Teach/246417/. Accessed 3 March 2020.

Kasriel, S. (2018). The future of work won't be about college degrees, it will be about job skills. CNBC, 8 November. https://www.cnbc.com/2018/10/31/the-future-of-work-wont-be-about-degrees-it-will-beabout-skills.html. Accessed 3 March 2020. 
Kazin, C., \& Clerkin, K.M. (2018). The potential and limitations of microcredentials. Service Members Opportunities Colleges. http://supportsystem.livehelpnow.net/resources/23351/Potential\%20and\%20 Limitations\%20of\%20Microcredentials\%20FINAL_SEPT\%202018.pdf. Accessed 6 April 2020.

Krupnick, M. (2018). As students flock to credentials other than degrees, quality control concerns grow. The Hechinger Report, 16 November. https://hechingerreport.org/as-students-flock-to-credentials-other-thandegrees-quality-control-concerns-grow/. Accessed 3 March 2020.

Labaree, D.F. (2010). How Dewey lost: the victory of David Snedden and social efficiency in the reform of American education. Revised version of a paper presented at the conference on "Pragmatism as the Reticle of Modernization: Concepts, Contexts, Critiques," Centro Stefano Franscini, Monte Verità, Ascona, Switzerland, September, 2008, 1-26. https:/edu301s2011.files.wordpress.com/2011/03/how_ dewey lost.pdf. Accessed 3 March 2020.

LinkedIn Learning (2018). Workplace learning report. Linkedin.com. https://learning.linkedin. $\mathrm{com} /$ content/dam/me/learning/en-us/pdfs/linkedin-learning-workplace-learning-report-2018.pdf. Accessed 3 March 2020.

López-Pérez, M.V., Pérez-López, M.C., Rodríguez-Ariza, L., \& Argente-Linares, E. (2013). The influence of the use of technology on student outcomes in a blended learning context. Educational Technology Research and Development, 61, 625-638. https://doi.org/10.1007/s11423-013-9303-8.

Maloney, E.J. \& Kim, J. (2019). How universities can avoid learning innovation theatre. Inside Higher Education, 30 October. https://www.insidehighered.com/digital-learning/blogs/technology-andlearning/how-universities-can-avoid-learning-innovation. Accessed 3 March 2020.

Maseleno, A., Sabani, N., Huda, M., Ahmad, R., Jasmi, K. A., \& Basiron, B. (2018). Demystifying learning analytics in personalized learning. International Journal of Engineering \& Technology, 7(3), 1124-1129. https://doi.org/10.14419/ijet.v7i3.9789.

McDonough, T. (2020). The case against education as usual. Inside Higher Education, 26 February. https://www.insidehighered.com/views/2020/02/26/colleges-should-much-more-deliberately-emphasizesoft-skills-they-say-they-provide. Accessed 3 March 2020.

McGarry, K. (2018). The skills gap: employers expect more than what college grads offer. Raleigh, NC: The James G. Martin Center for Academic Renewal, 3 April. https://www.jamesgmartin.center/2018/04/skillsgap-employers-expect-college-grads-offer/. Accessed 3 March 2020.

McLaren, S. (2016). How investing in employee training benefits your business. Entrepreneur Middle East, 16 May. https://www.entrepreneur.com/article/275842. Accessed 3 March 2020.

McNally, D. (1993). Against the market: political economy, market socialism and Marxist critique. New York: Verso.

Mintz, S. (2019). Educating versus training and credentialing. Inside Higher Education, 4 February. https://www.insidehighered.com/blogs/higher-ed-gamma/educating-versus-training-and-credentialing. Accessed 3 March 2020.

Mooney, C. (2015). Next: the credentials craze. The Chronicle of Higher Education, 14 September. https://www.chronicle.com/specialreport/Next-The-Credentials-Craze/2 . Accessed 3 March 2020.

Moroder, K. (2014). Micro-credentials: empowering lifelong learners. Edutopia, 7 April. https://www. edutopia.org/blog/micro-credentials-empowering-lifelong-learners-krista-moroder. Accessed 3 March 2020.

O’Malley, B. (2019). MOOCs fail in their mission to disrupt higher education. University World News, 23 January. https://www.universityworldnews.com/post.php?story=20190123080937857. Accessed 3 March 2020.

Patrick, F. (2013). Neoliberalism, the knowledge economy, and the learner: challenging the inevitability of the commodified self as an outcome of education. International Scholarly Research Notices. https://doi. org/10.1155/2013/108705.

Phelan, S. E., \& Glackin, C. E. (2020). A cautionary note on microcredentialing in entrepreneurship education. Entrepreneurship Education and Pedagogy. https://oi.org/10.1177/2515127419899599.

Ralston, S.J. (2019). Postdigital prospects for blockchain-disrupted higher education: beyond the theater, memes and marketing hype. Postdigital Science and Education, 2(2), 280-288. https://doi.org/10.1007 /s42438-019-00091-6.

Redden, E. (2020). 41\% of recent grads work in jobs not requiring a degree. Inside Higher Education, 18 February. https://www.insidehighered.com/quicktakes/2020/02/18/41-recent-grads-work-jobs-notrequiring-degree. Accessed 3 March 2020. 
Salin, J. (2019). Addressing the skills gap with micro-credentialing. Brightspace Community, 25 October. https://brightspacecommunity.force.com/s/article/Addressing-the-Skills-Gap-with-Micro-CredentialingPart-1. Accessed 3 March 2020.

Scott, R.A. (2018). The business model of higher education. HigherEdJobs, 23 April. https://www. higheredjobs.com/blog/postDisplay.cfm?post=1607\&blog=22. Accessed 3 March 2020.

Selingo, J.J. (2017). The future of the degree: how colleges can survive the new credential economy. The Chronicle of Higher Education, August. https:/www.pearson.com/content/dam/one-dot-com/one-dotcom/us/en/files/The-Future-Of-the-Degree-2017.pdf. Accessed 3 March 2020.

Seltzer, R. (2020). Purdue Global's next chancellor named. Inside Higher Education, 27 March. https://www. insidehighered.com/quicktakes/2020/03/27/purdue-globals-next-chancellor-named. Accessed 29 March 2020.

Sharples, M., \& Domingue, J. (2016). The blockchain and kudos: a distributed system for educational record, reputation and reward. In K. Verbert, M. Sharples, \& T. Klobučar (Eds.), Adaptive and adaptable learning. Lecture notes in computer science: EC-TEL. https://doi.org/10.1007/978-3-319-45153-4_48.

Siskin, C., \& Warner, W. (2019). Is it time to dezone knowledge? Inside Higher Education, 4 November. https:/www.insidehighered.com/views/2019/11/04/halt-crisis-humanities-higher-ed-should-rethink-itsclassification-knowledge. Accessed 6 April 2020.

Snedden, D. (1914/1977). Fundamental distinctions between liberal and vocational education. Curriculum Inquiry, 7(1), 41-52. https://doi.org/10.1080/03626784.1977.11076203.

Staton, M. (2015). When a fancy degree scares employers away. Harvard Business Review, 6 January. https://hbr.org/2015/01/when-a-fancy-degree-scares-employers-away. Accessed 3 March 2020.

Swinnerton, B., Coop, T., Ivancheva, M., Czerniewicz, L., Morris, N.P., Swartz, R., Walji, S., \& Cliff, A. (2019). The unbundled university: researching emerging models in an unequal landscape. In N.B. Dohn, P. Jandrić, T. Ryberg, \& M. de Laat (Eds.), Mobility, data and learner agency in networked learning (pp.19-34). Heidelberg: Springer. https://doi.org/10.1007/978-3-030-36911-8.

Tauqeer, M., \& Bang, K. (2018). Servitization: a model for the transformation of products into services through a utility-driven approach. Journal of Open Innovation: Technology, Market, and Complexity, 4(60), 1-20. https://doi.org/10.3390/joitmc4040060.

U.S. News and World Report (2020). 2020 best national university rankings. USNews.com. https://www. usnews.com/best-colleges/rankings/national-universities. Accessed 3 March 2020.

Walton, D. (2000). The place of dialogue theory in logic, computer science and communication studies. Synthese, 123, 327-346. https://doi.org/10.1023/A:1005237527730.

Watters, A. (2016). The blockchain for education: an introduction. Hack Education Blog, 7 April. http://hackeducation.com/2016/04/07/blockchain-education-guide. Accessed 3 March 2020.

Wilhelm, W.J., Logan, J., Smith, S.M., \& Szul, L.F. (2002). Meeting the demand: teaching 'soft' skills. Little Rock, AK: Delta Pi Epsilon Society. https://files.eric.ed.gov/fulltext/ED477252.pdf. Accessed 6 April 2020.

Williamson, J., \& Pittinksy, M. (2016). Making credentials matter. Inside Higher Education, 23 May. https:/www.insidehighered.com/views/2016/05/23/understanding-differences-what-credentials-arebeing-stacked-and-why-essay. Accessed 3 March 2020.

Willis, J.E., III, Strunk, V.A., \& Hardtner, T.L. (2016). Microcredentials and educational technology: a proposed ethical taxonomy. Educase, 18 April. https://www.academia.edu/24529014/Microcredentials and_Educational_Technology_A_Proposed_Ethical_Taxonomy. Accessed 6 April 2020.

Wingate, U. (2007). $\bar{A}$ framework for transition: supporting 'Learning to Learn' in higher education. Higher Education Quarterly, 61(3), 391-405. https://doi.org/10.1111/j.1468-2273.2007.00361.x.

Young, J.R. (2017a). At gathering on academic innovation, leaders wonder how fast colleges should change. EdSurge, 20 September. https://www.edsurge.com/news/2017-09-20-at-gathering-on-academicinnovation-leaders-wonder-how-fast-colleges-should-change. Accessed 3 March 2020.

Young, J.R. (2017b). The new frontier in online education: meet the microcredential. Slate, 10 October. https://slate.com/technology/2017/10/microcedentials-are-the-new-frontier-in-online-education.html. Accessed 3 March 2020.

Young, J R. (2019). Is there still a meaningful difference between for-profit and public higher ed? EdSurge, 30 May. https:/www.edsurge.com/news/2019-05-30-is-there-still-a-meaningful-difference-between-forprofit-and-public-higher-ed. Accessed 3 March 2020. 